\title{
Times of Change in Latin American Regionalism
}

\section{José Briceño-Ruiz*}

\begin{abstract}
After a decade dominated by post-liberal or post-hegemonic initiatives, the advent of conservative governments in Argentina and Brazil and the crisis in Venezuela have led to a resurgence of open regionalism. This could have important consequences in a region divided by different models of economic integration and political cooperation. The study evaluates the complex and changing scenario of Latin American regionalism. First, I trace the trajectory of regionalism in Latin America in recent years. Second, I examine models of economic integration and political cooperation. Third, I analyse the operation of those models in the post-hegemonic era. Lastly, I assess the emergence of a new regional cycle, and its implications for regional integration and cooperation.
\end{abstract}

Keywords: Regionalism; Regional Integration; Cooperation; Latin America; Post-hegemony.

\section{Introduction}

During the past three decades, Latin American regionalism has gone through several major phases, and moved back and forth in an apparently unpredictable manner. In the 1990s, regionalism was regarded as a mechanism for improving the region's global insertion; from 2003 onwards, however, regional processes were redesigned following the rise of left-wing governments in some countries. This led to a new period of post-liberal or post-hegemonic regionalism, in which an emphasis on free trade was replaced by the strengthening of the political, social and productive dimensions of regional initiatives.

One of the features of this post-hegemonic era was the increasing subregionalisation of economic integration that led to the emergence of three axes: the Southern Common Market (Mercosur), the Bolivarian Alliance for the People of the Americas (ALBA), and the Pacific Alliance. ${ }^{1}$ These subregional schemes were based on diverse, and in some cases contradictory, models of economic integration, and even on different models of political cooperation. This was accompanied by the creation of new spaces of South American and Latin American political and functional cooperation, notably the Union of South American Nations (UNASUR) and the Community of Latin American and Caribbean States (CELAC). Therefore, Latin American regionalism became a complex system of sub-

\footnotetext{
* Cooperative University of Colombia, Bogota, Colombia; bricenoruiz@hotmail.com. ORCID iD 0000-
} 0003-2710-4435. 
regional and regional initiatives based on different economic and political models, diverse approaches to the role of regionalism in national strategies of economic development, and diverse conceptions of the role of foreign policy. However, recent political changes in Argentina, Brazil and Ecuador and the political crisis in Venezuela suggest that this diversity is waning, and that the logic of open regionalism which was hegemonic in the 1990s could return.

Against this background, this study explores the question of whether recent political changes in Latin America signify the end of the post-hegemonic era. It argues that some regional integration schemes in the post-hegemonic period resulted from the emergence of different models of economic integration and political cooperation. Specifically, the dominance of neo-liberalism and US hegemony was contested. However, neo-liberalism and US hegemony did not disappear, and the establishment of the Pacific Alliance in 2011 provided further evidence that the anti-liberal and anti-US narratives had not become hegemonic in turn. The diversity of the region is further demonstrated by the fact that no single post-hegemonic model was developed in Central America (see Dabène and Parthenay 2017).

Thus, post-hegemonic regionalism meant the absence of any kind of hegemony. Regional blocs promoting economic models that were critical of neo-liberalism and political models that challenged US hegemony coexisted with other schemes committed to neoliberalism and close relations with the USA. As the 'turn to the left' manifested itself in different ways (Lula differed from Chávez, and Frente Amplio from Evo Morales), the nature and intensity of the criticism of neo-liberalism and US hegemony differed among the various post-hegemonic schemes.

Various political changes have occurred since 2015. Mauricio Macri's ascent to the Argentinian presidency is a conservative turn in the politics of that country. Macri has criticised the abandonment of trade objectives in Mercosur, and promised closer relations with the Pacific Alliance. He has also promised to 'bring Argentina back to the international community' after its alleged isolation in the Kirchner era. In Brazil, Dilma Rousseff has been impeached, and her successor, Michel Temer, has modified the Brazilian approach to regional integration. The criticism of neo-liberalism under Lula and Rousseff has disappeared, and Temer has promoted closer relations with the USA and the developed world. In Ecuador, Lenin Moreno has been elected with the support of Alianza País, the political movement led by Rafael Correa, but has distanced himself from his predecessor.

Venezuela is a different case. This country is experiencing a deep political and economic crisis. President Nicolas Maduro still loudly criticises neo-liberalism, and continues to confront the USA. However, the Bolivarian economic model is not an example to be followed, and the anti-US narrative has become more of a rhetorical tool and a means of evading his responsibility for the crisis than a real challenge to the USA, which remains Venezuela's main trading partner.

These political changes have weakened the government coalitions that promoted a regional strategy based on the combination of an economic model which rejected neoliberalism, and a political model which confronted the US hegemony. The regional blocs 
that promoted this combination were among the pillars of the post-hegemonic era, and their weakening is a signal that a new cycle of regionalism is under way. ALBA remains as a case of radical post-hegemonic policies, but its influence has declined. Even if Maduro succeeds in consolidating his authoritarian rule, ALBA seems unlikely to regain its regional influence.

In the analysis what follows, I start by examining the trajectory of Latin American regionalism over the past few decades. Next, I evaluate different models of economic integration and political cooperation. Following this, I examine the implementation of those models in the post-hegemonic era. Finally, I consider the political changes in some Latin American countries that are leading to a new cycle of regional cooperation.

An initial conceptual clarification is needed. 'Regionalism' is adopted as the main analytical concept. Regionalism is defined as an associative process that occurs in spatially delimited areas of the international system, called 'macro regions' or international regions. Several features define these regions. Firstly, although the element of geographical contiguity or proximity is a crucial variable, this is usually understood in a flexible way. Thus, the 'Americas' is regarded as a region, with the Organization of American States (OAS) as its institutional framework. The region is spatially delimited by the notion of a Western Hemisphere, promoted by the USA since the end of the $19^{\text {th }}$ century. This is similar to the Asia-Pacific Cooperation Forum (APEC), a 'macro region' whose member states are not geographically contiguous, but whose spatial scope is defined by the notion of the 'Pacific Rim.'

Secondly, an 'international macro region' is socially constructed. As Björn Hettne and Fredrik Söderbaum (2000: 38) assert, 'regions are political and social projects, designed by human actors to protect or transform existing structures.' Thirdly, regionalism is a state-led process that is usually formalised in an international treaty. However, this does not mean that other actors are excluded, because the construction of regions involves the participation of a diversity of economic, social and political actors. Finally, regionalism is a process with different manifestations and intensities, encompassed in initiatives of economic integration, economic cooperation, political integration, and political cooperation. The intensity of these modalities varies. For example, regional economic integration can range from a basic free trade area to a monetary union, but can go far beyond the trade dimension to include a strategy for the integration of production.

\section{Changing regionalism in Latin America during the past few decades}

Latin American regionalism was transformed in the 2000s. Pedro Motta Veiga and Sandra Rios (2007) describe this as 'post-liberal regionalism', while José Antonio Sanahuja (2010) prefer the term 'post-liberal regional integration.' Diana Tussie and Pia Riggirozzi (2012) use the term 'post-hegemonic regionalism' to describe a rupture with the narratives and models of the 1990s. As these terms imply, regionalism in that decade was associated with the triumph of neo-liberalism and the spread of globalisation, and the notion of posthegemonic regionalism proposes that new narratives beyond free markets and free trade 
emerged in Latin America in the first decade of the new millennium. This does not mean, however, that all regional schemes in Latin America broke with neo-liberalism. According to Riggirozzi (2012: 35), the emergence of a post-hegemonic regionalism 'does not mean that capitalism, liberalism and trade-related forms of integration cease to exist or to move the regional agenda. What this means is that their centrality is being displaced.' Although it is indisputable that regionalism is driven in part by economic considerations, the rationale of the new process in Latin America is not restricted to the promotion of trade, or opposition to the US hegemony (Riggirozzi 2010: 1).

In this article, I draw a distinction between 'post-liberal' and 'post-hegemonic' when analysing Latin American regionalism. In this approach, 'post-liberal' refers to concrete policy measures implemented by regional groups to surmount the neo-liberal bias that prevailed during the era of 'new regionalism.' Post-liberal refers to policy, with Mercosur's Strategic Plan of Social Action approved in 2011 as an example. By contrast, 'post-hegemonic' is a heuristic term used to explain a period in the history of Latin American regionalism with no unique narrative about what integration and cooperation are about. For example, UNASUR emerged in the post-hegemonic era, and adopted post-liberal policies such as the establishment of the Bank of the South. The Pacific Alliance was also born in the post-hegemonic era, but remains committed to neoliberalism.

The landscape of regional integration and cooperation in Latin America was also transformed in the post-hegemonic era, undergoing a degree of fragmentation. While some countries (such as Colombia, Chile, Mexico, Peru and most of the Central American states) remained committed to open regionalism and free trade, new conceptions of regional economic integration emerged in Argentina, Brazil, Bolivia, Ecuador and Venezuela. As a result, new axes of regional economic integration - the so-called 'new Mercosur', ALBA, and the Pacific Alliance - were created. These three axes were the most dynamic areas of economic integration in Latin America. Despite their efforts to maintain trade and political cooperation, old processes such as the Andean Community and (to a lesser extent) the System of Central American Integration (SICA) lost relevance in the academic debates.

This trend towards fragmentation in the field of economic integration was accompanied by the strengthening of political and functional cooperation at the South American, Latin American and Caribbean levels, with the creation of UNASUR in 2008 and CELAC in 2011 as outstanding examples. These initiatives countered the trend towards regional fragmentation.

On the one hand, a gradual process of the construction of South America as an international region was developed. This process began in 1993, when the Brazilian president Itamar Franco proposed the creation of a South American Free Trade Area (SAFTA), perceived as a counterbalance to the North American Trade Agreement (NAFTA). In 2000, the process was relaunched when the Brazilian president Fernando Henrique Cardoso convened the first summit of South American Heads of State and Government, and proposed the creation of a South American Community of Nations, or SACN (CASA in Portuguese, CSN in Spanish), which was formally institutionalised in Cuzco in December 
2004. In 2008, the SACN was transformed into UNASUR, an ambitious regional cooperation scheme with a maximalist agenda and a strong political dimension (see Briceño Ruiz 2010; Serbin 2009; Sanahuja 2011). Trade was not the most important issue in UNASUR. Some proposals to foster South American trade were presented to the South American Council of Economy and Finance, but due to a lack of consensus they did not succeed (see Briceño-Ruiz and Ribeiro Hoffmann 2015). The promotion of financial mechanisms such as the Venezuelan project of the Bank of the South were subsumed under UNASUR, but its progress was limited by the scepticism of Colombia, Chile and Peru. This notwithstanding, issues such as infrastructure, security and defence, conflict resolution, and public health drove UNASUR's agenda.

CELAC, a multilateral Latin American and Caribbean regional scheme, was founded in Caracas in December 2011. Emerging from the Latin American and Caribbean Summit (CALCS) and the meetings of the Rio Group, CELAC is an effort to set up a space for dialogue and cooperation among all Latin American and Caribbean countries (see Costa Vaz 2010; Rojas Aravena 2012). Economic integration is not a CELAC objective; as a result, it cannot be regarded as a complement to the Latin American Integration Association (LAIA; ALADI in Spanish and Portuguese). CELAC's goals are political cooperation, security, and the defence of human rights. There has been a debate on how to reconcile CELAC's functions with those of the OAS, the central institution of Inter-American cooperation, which was severely criticised after the Malvinas War in 1982.

Therefore, from the turn of the millennium, Latin American regionalism was marked by a contradictory dynamic, namely the coexistence of centrifugal and centripetal forces that promoted both union and fragmentation. In the economic sphere, the problem was that the different axes followed diverse (and sometimes contradictory) models of economic integration. To complicate things even further, the axes of economic integration followed certain types of political behaviour - put differently, while they were are largely aimed at achieving certain economic goals, this did not mean that politics were not involved. Thus, the three axes coincided to varying degrees with efforts at political cooperation, driven by diverse logics and interests.

These logics of unity and fragmentation were linked to specific models of economic integration and political cooperation. In what follows, I will examine these models in greater detail, explain their emergence in Latin America, and outline their relation to the axes of economic integration and the logic of unity and fragmentation. Lastly, I will examine the extent to which the new regional scenario that has emerged since 2015 could modify this logic of unity and fragmentation.

\section{Models of economic integration in Latin America}

This section analyses models of economic integration adopted in Latin America over the past few decades. Drawing on Weber, I argue that three ideal-type economic models have been adopted, namely strategic regionalism, social regionalism, and 'productive regional- 
ism' (based on the integration of production). Analysing them exhaustively is beyond the scope of this paper, but their fundamental features are presented.

Strategic regionalism is a form of regionalisation marked by 'strategic trade policy', based on some premises of the new theory of international trade developed in the 1980s. These were the existence of certain forms of monopolistic competition, and the need for states to support certain strategic economic sectors (see Brander 2005; Richardson 1990, 1992). This model boomed following the wave of economic integration that began in the late 1980s, and is regarded as a manifestation of the 'new regionalism.' One of its pillars is the insertion of integrated regions into the global economy, described as 'open regionalism. Free trade is a crucial component of this model. However, as in the case of strategic trade policy, those sectors considered as vital for economic development are excluded from the regional free trade regime.

Strategic regionalism developed as a response of states, in alliance with Transnational Corporations (TNCs), to the global post-Cold War world. Regionalism forms part of the strategies of some countries to 'manage' the process of globalisation in a more coherent way. One way of doing so is to adopt a 'deep integration' agenda, a concept developed by Robert Lawrence. Traditional integration agreements were aimed at facilitating access to markets through abolishing tariffs and removing non-tariff barriers, but this was just 'shallow integration.' In a context of trade liberalisation and financial globalisation, that form of integration was quite limited, which is why Lawrence proposed a deepening of the integration agenda to include 'trade-related' issues such as investments, intellectual property, public procurement, and labour and environmental standards (Lawrence 1996).

However, 'deep integration' varies between North-South agreements and South-South agreements. The former refers to integration initiatives that encompass developed and developing countries; in this instance, the most advanced nations are interested in promoting a 'deep integration' agenda, and require Southern countries to approve rules about investment, services or intellectual property as a payoff for greater access to their markets. South-South agreements, that is, those only involving developing countries (even those described as 'emerging economies'), tend to exclude a 'deep integration' agenda.

Yeates (2005), Deacon et al (2007) and Riggirozzi (2014, 2017) have argued that regionalism is not just a mechanism for promoting trade and investment, but also a space for approving and implementing regional social policy. Regionalism is conceived as a mechanism for establishing social standards at a regional level, fostering redistributive policies, and even creating institutions that allow citizens to demand the protection of their social rights. Thus, the implementation of this regional social policy includes measures to reduce the negative effects of trade liberalisation, and mechanisms to diminish existing asymmetries among and within countries. Going beyond this argument, Riggirozzi proposes that regionalism could be a mechanism for advancing poverty reduction agendas, and for 'leveraging regional approaches in dimensions important for human development, such as health, education, and the environment' (Riggirozzi 2017: 3). This model is described as 'social regionalism.' 
The third model is 'productive regionalism,' and refers to the creation of mechanisms for integrating the production of the countries participating in a given regional scheme. This model reinvigorates ideas of the structuralist school of the Economic Commission for Latin America, or ECLAC (Prebisch 1959; ECLAC 1959; Di Filippo 1995) and French structuralism (Perroux 1966; Marchal 1965, 1970; Renard 2001), in which economic integration is conceived as a way to foster a change in the pattern of production. In the early 1990s, ECLAC advanced the idea of a new pattern of production with social equity, linked to a model of international insertion based on open regionalism (Fajnzylber 1990; ECLAC $1990,1994)$. In recent years, these proposals have been revived by ECLAC itself (see, for example, ECLAC 2014; Egler et al 2014), as well as institutions such as the United Nations Conference on Trade and Development (UNCTAD 2007). The objective of the model of 'productive regionalism' is the integration of production, joint industrial development, and the unification of economies on a basis of solidarity. However, this model does not imply a return to an 'inward growth' strategy, but rather what Osvaldo Sunkel (1991) describes as 'growth from within.' This means using endogenous capacities and national resources to promote productive diversification, particularly industrialisation, but based on the premise that this process does not contradict improved insertion into world markets, or attracting foreign investment. Therefore, the model of 'productive regionalism' no longer proposes the development of large regional industrial projects, but the creation of productive chains of value in which local, national, regional and transnational firms participate.

These three models of economic integration exist in pure or combined form. Thus, a process of regional integration may opt for a model of pure strategic regionalism. NAFTA is a paradigmatic example of North-South strategic regionalism, while Mercosur is an example of a hybrid model, in which elements of all three models coexist.

\section{Models of political cooperation}

These models of economic integration do not explain the development of initiatives such as CELAC and UNASUR, or allow an adequate evaluation of the 'non-economic' dimensions of the Pacific Alliance, Mercosur and ALBA. For this reason, I also outline three models of political cooperation: the acquiescent realism model, the autonomist model, and the counter-hegemonic model.

The model of acquiescent realism is associated with the notion of 'peripheral realism,' developed by the Argentine scholar Carlos Escudé. In his view, peripheral countries have to realistically accept their weaknesses and vulnerabilities, and their lack of relevance in world politics due to global power asymmetry. In a globalised and transforming world, and in a 'peripheral' situation, the defence of ideas of autonomy as a guiding foreign policy principle must be revisited. Instead, peripheral countries should seek to foster alliances with major powers, and avoid conflicts that would later detract from their national interests (Escudé 1992). The model of acquiescent realism proposes a convergence of interests between a peripheral regional bloc and a hegemonic power or powers. 
The autonomist model is related to the ideas of Juan Carlos Puig and Helio Jaguaribe. For Puig, autonomy is a fundamental goal, aimed at guaranteeing that a country could neutralise the hegemonic behaviour of third countries. Autonomy is defined as 'the maximum capacity for self-decision that a country could have, considering the objective conditions of the real world' (Puig 1980: 148). This implies improving economic and military structures, and forming defensive alliances. For Puig, in the context of the Latin American reality, attempts to overcome dependence in isolation are 'not viable.' Greater autonomy from industrialised societies can only be achieved through integration with other countries that are similarly dependent, and pursuing similar autonomist goals (Arrosa Soares 2005: 4). According to Jaguaribe, the centre-periphery division of the international system and its relation to the degree of autonomy must be understood in relative terms, since there is a grey area between autonomy and dependency. Not all the countries of the 'centre' are autonomous, and not all the countries on the periphery lack autonomy. Instead, Jaguaribe describes the international system as a hierarchical one marked by international stratification (described as 'inter-imperial'). At the top of the hierarchy are countries that have a position of general primacy, and control their decisions, and at the bottom are those which depend upon decisions and factors that are not under their control (see Jaguaribe 1985). For Jaguaribe, Latin American countries have the potential to become more autonomous, depending on two structural factors: national viability, and international permissibility. National viability refers to the existence, at a particular historical moment, of a critical minimum of human and natural resources, the capacity for international exchange, and the degree of socio-cultural cohesion within national borders (Jaguaribe 1968: 102). International permissibility implies a greater capacity to neutralise possible coercion by third countries (Jaguaribe 1985), and depends on a given country's economic and military capacity to promote alliances with third countries. Jaguaribe also identifies two additional conditions for the achievement of autonomy: technological and business autonomy, and favourable relations with the predominant global power (the USA).

The notion of 'autonomy' has long had an impact on the debates about regional integration in Latin America, leading to proposals of a 'solidarity integration.' Based on these ideas, the 'autonomist model' is defined as one in which a group of countries on the periphery use regionalism as a mechanism for adopting common policies on security and defence, the protection of human rights, the defence of democracy, and functional cooperation, without these policies being subordinated to the existence of an external hegemon. These policies aim to augment the room for manoeuvre vis-à-vis external powers, but this does not imply a challenge to the existing world order. On the contrary, autonomy means (or is usually accompanied by) cordial relations (although autonomous and nonsubordinated) with a hegemonic power or powers.

The third model is 'counter-hegemonic regionalism, adopted by 'revolutionary states' to expand their internal revolutions to the international system. According to Rucker (2004: 110), a revolutionary state is one that seeks not only 'to improve its relative position in the configuration of the balance of power,' but also to export the principles of the revolution and, 'therefore, to question the norms, values, relations between actors on the inter- 
national scene.' Fred Halliday (1994: 90) argues that one of the international consequences of the existence of 'revolutionary states' is their compulsion to 'export' their revolutions. In Halliday’s (1994: 90) words:

$[\mathrm{R}]$ evolutionary states see an internationalisation of their struggle as part of domestic consolidation: militarily, in the gaining of likeminded allies; economically, in the winning of collaborative relationships with such allies; and ideologically, in the promotion at the international level of similar ideals to those which legitimate their own regime.

Regionalism could be one of the mechanisms used by a 'revolutionary state' to challenge and confront the hegemony of a global and regional power. Thus, regionalism becomes a counter-hegemonic alliance aimed at transforming both the regional and the global structure of power.

\section{Models of regionalism in the post-hegemonic era}

The models of economic integration and political cooperation described in the previous section coexisted in the post-hegemonic era. This is quite natural if we consider that one the features of post-hegemonic regionalism is the absence of a unique and hegemonic model of and narrative about regionalism. In consequence, despite the predominance of left-wing governments, Latin American regionalism in this period was marked by diversity.

Firstly, Mercosur moved from a model of strategic regionalism to elements of social regionalism and the integration of production. The Pacific Alliance became a new case of strategic regionalism, and ALBA developed a particular approach of social regionalism. In the sphere of political cooperation, while Mercosur was an example of an 'autonomist' model, the Pacific Alliance was one of acquiescent realism, and ALBA one of contra-hegemonic regionalism.

Mercosur was originally an example of strategic regionalism. The goals in the Asunción Treaty were the achievement of a free trade area and a common external tariff as mechanisms for improving the insertion of the bloc into the global economy. However, some sectors considered strategic for Argentina and Brazil, such as the automobile industry and sugar, were excluded from trade liberalisation. The role of transnational firms was crucial in the automobile sector, but also Brazilian and, to a lesser extent, Argentine firms that were expanding their economic activities played an important role in the early development of Mercosur.

However, this model of strategic regionalism was at least partially modified during the post-hegemonic era by including elements of social and productive regionalism. To be fair, this transformation evolved gradually throughout the 1990s, but deepened after 2003 when left-wing presidents rose to power. The new leaders reviewed the model of strategic regionalism without formally rejecting free trade, but did so in the belief that, due to the 
structural conditions of the Southern Cone, free trade was not enough. In consequence, they complemented Mercosur's trade dimension with social and productive dimensions. Thus a Council of Ministers of Social Development was established in 2005, and the Mercosur Social Institute was set up in 2007. An ambitious Strategic Plan of Social Action was approved in 2011, aimed at reducing poverty, redistributing wealth, promoting social justice, and regulating market institutions. A new Socio-Labour Declaration was approved in July 2015. Similarly, Mercosur gradually rekindled the idea of using regional integration to foster the integration of production, i.e., regional industrialisation. Some important decisions were taken, such as the creation of a Fund for Structural Convergence (FOCEM in Spanish) in 2005, the creation of a Fund for Small and Medium Businesses in 2008, and the approval of a Regional Programme for the Integration of Production in 2008.

As regards political models, even if the rise of Mercosur in the 1990s was linked to the process of democratisation in the Southern Cone, its political dimension was overshadowed by the overwhelming dynamics of trade and economic affairs. Despite the ascent of the Carlos Menem government, Mercosur never adopted the model of acquiescent realism. In other words, Mercosur never pursued the 'carnal relations' with the USA advocated by the Argentine Minister of Foreign Affairs, Guido di Tella. One example of this was the Brazilian criticism of the FTAA project which began with the early Ministerial Summits. Despite this, Mercosur did not openly adopt an autonomist model, but did embark on more autonomous conduct with the advent of the post-hegemonic era. Thus, important leaders of the regional bloc embraced the rhetoric of the construction of a multipolar world. For example, in a speech delivered in 2007, Cristina Fernández de Kirchner declared: 'We will continue to advocate a multipolar world, the multipolarity that gives balance in international relations. Unilateralism has created only tragedy, pain and insecurity in the contemporary world. We have to rebuild the lost balance, and Mercosur must also be a leader.'

Similarly, Samuel Pinheiro Guimarães, High General Representative of Mercosur between January 2011 and June 2012, pointed out that

[...] in the process of integrating Mercosur and South America in political relations with [...] the violent multipolar world in which we live, Brazil and Argentina are united by the common objectives of transforming international relations, in the sense that the rules governing relations between states and economies are of such a nature that countries such as Brazil and Argentina continue to do what is needed to prepare end implement development policies that allow overcoming inequalities, defeating vulnerabilities, and achieving the potential of their societies (Pinheiro Guimarães 2008: 70-71).

Mercosur also accepted Venezuela and Bolivia - both with anti-US governments - as full members. Mercosur never adopted their anti-US rhetoric, but the presence of Chávez in the regional bloc was a signal of greater autonomy vis-à-vis Washington. Furthermore, Mercosur stepped up criticism of the FTAA to the point where this led to the collapse 
of the Summit of the Americas held in Mar del Plata in 2004. Mercosur suspended the negotiation of Association Agreement with the European Union, and did not promote North-South agreements.

Some analysts have argued that ALBA should not be seen as an economic integration initiative, but as a space for economic and political cooperation (Buck 2010: 397). This is probably true about ALBA's early years, but not about its further evolution. Inter alia, ALBA seeks to promote Grand-National Companies to undertake joint industrial projects. Similarly, a Regional Clearance Unitary System (SUCRE in Spanish) was established in 2009, and an ALBA economic zone (known as Eco ALBA) in 2012. All these initiatives clearly constitute forms of economic integration. ALBA was originally a fuzzy proposal simply aimed at confronting the FTAA. It was a unilateral initiative announced by Chávez at the Summit of Heads of State and Government of the Association of Caribbean States (ACS) held in December 2001 on Margarita Island, Venezuela. No public documents explaining its objectives and mechanisms were published until 2003, and when they were, they were mostly devoted to criticising the FTAA and presenting 'alternative proposals' to those that were being negotiated in the hemispheric process (see, for example, Chávez 2003). A new period began in December 2004 when Fidel Castro and Chávez met in Havana to transform ALBA from an alternative to the FTAA into a regional project that began to be described as a new model of integration. Its purported goal was 'the transformation of Latin American societies, making them fairer and more educated, participatory and supportive' (Agreement between the Presidents of Venezuela and Cuba 2004).

Given this, it could be argued that ALBA has been based on a model of social and productive regionalisms; however, the latter characterisation would need to be clarified. Firstly, ALBA has developed a strong social dimension, but has not established regional social regulations and institutions that allow people to demand the protection of social rights. Furthermore, ALBA's social strategy is based on the ideas of 'buen vivir' and 'vivir bien,' which are closely related to Andean indigenous cultures rather than to the traditional concept of the welfare state.

Secondly, the integration of production under ALBA is not based on structuralist proposals of setting up regional industries, or more recent proposals for fostering regional value chains. The only mechanism that seems to approximate the model of productive regionalism is the Grans-National Companies, but this proposal is still quite fuzzy and ill-defined.

At the political level, ALBA is an example of a counter-hegemonic model. Firstly, it is conceived as part of a process aimed at creating a multipolar world. The goal of building a multipolar order has been maintained, but has gradually been replaced by an antiimperialist discourse. Secondly, ALBA promotes the rejection of neo-liberalism, which is an international projection of the Venezuelan economic strategy that replaced the policies of structural reform. Thus, it was not only a criticism of the adoption of national economic policies inspired by neo-liberal ideas, but also of the way in which these had become the basis of Latin American regionalism. The struggle against neo-liberalism was transformed after 2004 into a rejection of the capitalist system and the promotion of 'the $21^{\text {st }}$ century 
socialism.' It was no longer a critique of the neoliberal approach to building capitalism, but of the capitalism system itself. Based on these criticisms, ALBA has proposed the creation of a Latin American bloc capable of influencing world politics, and confronting existing powers.

To some extent, the Pacific Alliance is linked to the free trade agreements (FTAs) between its current members and the USA. However, its real antecedent is the Latin American Pacific Arc, a grouping proposed by the Peruvian president Alan Garcia in 2006. This was a regional scheme pushed by governments that remained committed to structural reform and trade liberalisation, and had concluded FTAs with the USA. The Pacific Arc was transformed into the Pacific Alliance in April 2011 when Colombia, Chile, Peru and Mexico acted to establish a new regional bloc aimed at promoting 'deep integration' and free trade (Lima Presidential Declaration 2011).

The Pacific Alliance has attracted growing attention in both political and academic circles in recent years. This is due to its rapid institutional consolidation, marked by the signing of the Pacific Alliance Framework Agreement in June 2012. Its members have never been interested in post-liberal policies, or the adoption of post-hegemonic narratives. On the contrary, they remain strongly committed to the logic of a new and open regionalism. They have been more interested in the effects of international events such as the stagnation of the Doha Round of the World Trade Organization (WTO), the emergence of China and its increasing presence in Latin America, the US strategy of promoting bilateral FTAs (not limited to the Western hemisphere), and the participation in macro regional processes such as the Transpacific Partnership (TPP). For Chile, Colombia, Mexico and Peru, a major concern has been to avoid the erosion of trade preferences in the markets of their main trading partners (Briceño Ruiz 2017).

Therefore, it is valid to argue that the Pacific Alliance is an example of strategic regionalism. It remains committed to a 'deep integration agenda', as recognised in the Lima Declaration, in which the presidents of participating states agreed to create an 'area of deep integration through a process of political, economic articulation and cooperation and integration in Latin America' (Lima Declaration April 2011). Neither the Lima Declaration nor the Framework Agreements state a commitment to subscribe to WTO-plus rules, but the four member countries have already adopted them in any case, notably in terms of bilateral free trade agreements with the USA. However, as noted previously (see Briceño Ruiz 2013), the Pacific Alliance is a case of South-South strategic regionalism with WTO-plus rules. In terms of Max Weber's terminology, this is a deviation from an ideal type. Weber argued that ideal types are mental constructions or 'rational utopias' that are rarely realised empirically. Accordingly, it is possible and relevant to determine to what extent reality falls short of an ideal type - a sociological notion known as deviation. However, deviations from an ideal type do not destroy the latter's heuristic function. The idea of deviation also helps to avoid having to extend a typology ex post facto.

The Pacific Alliance can be regarded as a deviation from the ideal type of South-South strategic regionalism. Despite being a South-South agreement, the Alliance has promoted a deep integration agenda with WTO-plus agreements. These aspects are more typical of 
the North-South variant of the strategic regionalism model. This deviation is explained by the fact that the members of the Alliance had already signed FTAs in which WTO-plus rules had been adopted. Except for this anomaly, the Alliance conforms to the model of strategic regionalism.

The political and strategic dimension of the Pacific Alliance should be highlighted. This is a sensitive issue for promoters of this regional bloc that conceive it as just a trade agreement without political connotations. Characterising the Pacific Alliance as a US conspiracy to weaken UNASUR or Mercosur are indeed simplistic. It is one thing that the Pacific Alliance has been influenced by the logic of a new and open regionalism promoted in the FTAs and FTAA, and quite another to argue that the new regional grouping is a US creation. The Pacific Alliance is the result of decisions made by governments committed to free trade and open regionalism, not only with the USA but with the rest of the world (Briceño Ruiz 2017). Different motivations exist. Firstly, the Pacific Alliance implies a weakening of the associations [Mercosur and UNASUR] that Brazil has supported in order to wield its power and influence in the area' (Saltalamacchia Ziccardi 2014: 430). Secondly, the Pacific Alliance aims not only to balance out Venezuela, but also to present an alternative narrative to the non-capitalist model of integration promoted by Caracas. While Chavez used ALBA to promote his anti-systemic and anti-capitalist view of regional integration and cooperation, the Pacific Alliance is a mechanism for affirming and reproducing the liberal identity claimed by its four members. As Saltalamacchia Ziccardi (2014: 433) has pointed out,

the Pacific Alliance can be seen as the sponsor of an ideological alternative that competes in the market of ideas with other paradigms such as the Brazilian and Argentinean neo-structuralism, or the ' $21^{\text {st }}$ century socialism' advocated by Venezuela. So, if ALBA countries use their platform to promote in Latin America a 'great anti-neoliberal narrative. ... the Pacific Alliance counteracts promoting a 'proliberal narrative.'

Therefore, it is valid to argue that the Pacific Alliance is an example of the model of acquiescent realism.

While the subregional associations created by Latin American countries opted for different models of political regionalism, there was at least a lowest common denominator in the South American regional project represented by UNASUR, and the Latin American one represented by CELAC. Two aspects need to be considered when analysing these associations. Firstly, they have no trade goals: neither UNASUR nor CELAC is aimed at establishing a free trade area, customs union, or common market. One could argue that UNASUR has a financial dimension, evidenced by the proposed Bank of the South, but beyond this no other economic goal can be found. As a result, they cannot be classified in terms of conventional models of regional integration. Secondly, both schemes are politically diverse - at one point, UNASUR encompassed Hugo Chávez, Lula da Silva, Cristina 
Kirchner, Evo Morales, Alvaro Uribe, Alan García and Sebastian Piñera. In this context, it was difficult for a single model of political cooperation to prevail. CELAC is a similar case.

Therefore, both CELAC and UNASUR were based upon a lowest common denominator, namely a desire to push aside the revolutionary objectives of ALBA countries on the one hand, and the idea of a convergence of interests with the global hegemon of the Pacific Alliance on the other, but without adopting a model of total autonomy. This explains, at least partially, the stagnation of both regional schemes. For example, diverse positions among CELAC members about the Venezuelan crisis have prevented this regional grouping from convening a meeting to discuss the issue. Similarly, some UNASUR proposals have failed due to a lack of consensus, a prominent example being the Bank of the South, which was approved but never implemented due to the scepticism of some member states. By contrast, progress has been made in areas in which consensus exists, such as cooperation on health and pharmaceuticals.

\section{A new cycle: the end of heterogeneity?}

If a new cycle has started in Latin American regionalism, Mercosur is a key case to study. The reason for this is obvious: Argentina, Brazil and Venezuela, three leading members of Mercosur, are at the centre of the political storm that has lashed Latin America during the past few years. In the post-hegemonic era, Mercosur implemented policies associated with the model of social and productive regionalism, and put aside elements of strategic regionalism adopted in the early years of regionalism. These policies were aimed at replacing the bloc's alleged neo-liberal bias. As regards the political dimension, Mercosur opted for a more autonomous foreign policy that led to greater distance from the USA.

Thus the 'New Mercosur' was a clear example of a post-hegemonic logic that combined policies to confront the hegemony of neo-liberalism and the USA. The rise to power of more conservative governments in Argentina and Brazil and the crisis in Venezuela have undermined those policies. As regards economics, both the Argentine president Mauricio Macri and Brazilian president Michel Temer have developed critiques of Mercosur's activities over the past decade, and for Mercosur, free trade has once again become a central issue. According to Paulo Estivallet de Mesquita, Sub-Secretary for Latin America of the Brazilian Ministry of Foreign Affairs, Macri and Temer agree on the abolition of all trade barriers in order to transform Mercosur into a free trade area able to negotiate with other countries and regional blocs, noting that: ' $[\ldots]$ the perception of Argentina and Brazil is the idea of completing the free trade of all products within Mercosur. The two governments have micro and macroeconomic convergence, and consider that it would be better for everyone to fulfil with the elimination of all barriers' (Ambito.com 2017).

At a summit meeting with Macri held in Brasilia in February 2017, Temer spoke of 'achieving the elimination of barriers to trade that still exist in Mercosur' (Perfil 2017).

Moreover, Mercosur has relaunched negotiations about an Association Agreement with the EU and has fostered a free trade agreement with the Pacific Alliance, an idea initially proposed by the Chilean president Michelle Bachelet and subsequently supported 
by Macri. Similarly, Mercosur has expanded its preferential trade agreement with India. These initiatives have been backed by Paraguay and Uruguay, which have pushed for a deepening of the trade dimension in Mercosur. By contrast, references to Mercosur's social and productive dimensions have diminished since the rise to power of Macri and Temer. Neo-liberal policies have reappeared at the national level in Argentina and Brazil, resulting in the resurrection of the narrative of the model of strategic regionalism.

The political dimension is a more complex issue. Even if Argentine foreign policy in the Kirchner era did not display a Chávez-style anti-US rhetoric, relations with Washington were distant. Macri has clearly stated his interest in closer relations with the USA and Western Europe. This strategy was announced in a document entitled Seremos afuera lo que seremos adentro (We will be outside what we will be inside), published in 2014 by the Argentine Council of International Relations (CARI), a think-tank close to Macri. Thus, it is clear that Argentina in the Macri era is no longer committed to the autonomist model. Nevertheless, this shift in the Argentine strategy has not led Mercosur to adopt the model of acquiescent realism. This is because, despite Brazil's 'turn to the right,' autonomy is a guiding principle of Brazilian foreign policy, irrespective of the ideological orientation of the government of the day.

However, it has led to improved relations between Mercosur and the region's biggest hegemon, the USA. A key example is the crisis in Venezuela. Mercosur and the USA both regard Nicolás Maduro's government as an authoritarian regime. Indeed, Mercosur suspended Venezuela's membership in 2017 after the controversial election of a new National Assembly, called by presidential decree, which has not been recognised by Mercosur, the USA, other Latin American countries, and the European Union.

Therefore, following the rise to power of Macri and Temer, the combination of antiliberal and anti-US policies that characterised the 'new Mercosur' of the post-hegemonic era have been weakened to the point of being decimated. The regional policies associated with social regionalism (the Strategic Plan of Social Action) and productive integration (the Programme of Integration of Production) remain in place, but are no longer priorities for the new governments. Closer relations with the USA and other developed countries are a priority, so the autonomist model of political cooperation has been superseded.

The case of ALBA is different. One of its major weaknesses has always been its dependence on Venezuelan funding, which has progressively dried up. As a result, while the rhetoric about social issues is being maintained, its ability to promote a 'social internationalism' has been circumscribed. This is also true of the so-called Grand-National Companies, a bizarre attempt to integrate production that has produced more words than deeds. As a result, while ALBA formally still seeks to promote the model of social and productive regionalism, the level of implementation is quite weak. As regards the political model, ALBA remains a 'counter-hegemonic bloc' in formal terms, but the economic crisis in Venezuela is undermining its capacity to undertake any regional programmes ALBA member states may continue to exercise what amounts to a minority veto in other regional institutions such as the OAS, but its capacity to set the regional agenda is limited. 
The Pacific Alliance is the regional bloc least affected by the regional political changes, because its members never accepted post-liberal policies. Thus, the Alliance will continue pursuing an economic model of strategic regionalism, probably seeking a convergence with Mercosur. Similarly, it will probably maintain a model of acquiescent realism in the political sphere.

UNASUR and CELAC, which have functioned at the level of the lowest common denominator, could also be reconfigured if the conservative governments consolidate. In the meantime, both regional initiatives remain paralysed. The crisis in Venezuela has exposed CELAC's limitations, despite some progress in the promotion of political dialogue with external actors such the EU and China. If CELAC is the institutional framework for the political discussion of regional affairs, it is legitimate to ask why the Lima group needs to be created to debate the Venezuelan crisis.

UNASUR is a similar case. It is even more stagnant than CELAC. It succeeded in resolving a political crisis in its early years, but its role as mediator in the Venezuela crisis has not only been a total failure, but has also raised doubts about the neutrality of the mediators. As is widely known, UNASUR has not been able to agree on appointing a new general secretary. This suggests that the lowest common denominator that allowed UNASUR to function in its early years has reached its limits. The political changes in Argentina, Brazil and Ecuador and the Venezuelan crisis are among the factors that have put UNASUR and CELAC in crisis.

At the same time, the situation remains fluid. Regionalism during the past decade has been described as post-hegemonic because blocs that combined social and productive regionalism in the economic domain with autonomist or counter-hegemonic models in the political sphere coexisted with regional schemes that favoured strategic regionalism in the economic domain, and acquiescent regionalism in the political one. That meant that there was no hegemony in either the economic or the political sphere. This regional heterogeneity is diminishing, in both ideological and policy terms, and if this trend persists, a new hegemony could develop. The results of the elections in México, Brazil and Colombia in 2018 and the resolution of the Venezuelan crisis will play vital roles in determining whether the current conservative trend in regional politics will be consolidated.

\section{Conclusions}

Latin American regionalism has been characterised by the search for a model conforming to the national development strategies of member countries. The problem has been that, for almost a decade, the region was divided between those governments that remained committed to neoliberalism and the Washington Consensus, and those that opted for socalled post-liberal policies and narratives of economic development. This affected economic integration, and led to the emergence of different models of economic regionalism (ALBA, the 'new Mercosur' and the Pacific Alliance) as well as diverse foreign policy practices. Thus, political diversity in the region produced a subregionalisation, and in some cases (notably ALBA and the Pacific Alliance), conflicting views of what regionalism is 
about. Notwithstanding this increasing diversity at the subregional level, South American and Latin American regional institutions were also created with the participation of countries that promoted different models of economic integration and political cooperation at the subregional level. This led to centrifugal and centripetal forces working simultaneously, as well as growing fragmentation and diversity. This also had an impact on the academic debate, with a literature emerging about overlapping regional schemes, regional governance complexes, and complex international regimes (see Gómez Mera 2015; Nolte 2014).

However, the recent political changes in Argentina, Brazil and Ecuador and the political crisis in Venezuela raise questions about the continuation of this diversity, a possible return of the model of strategic regionalism, and the weakening of the models of social and productive regionalism, especially in Mercosur. In the political sphere, acquiescent regionalism seems to be waxing, while the autonomist trend is waning. The counter-hegemonic model followed by ALBA is declining, despite momentary successes like the common action in the OAS to block the evaluation of the Venezuelan political and economic crisis in 2017. Furthermore, the active participation of the OAS in the Venezuelan crisis could further weaken CELAC and UNASUR. The latter regional scheme in particular has lost the crisis resolution capacity displayed in its early years, and its failure to mediate in the Venezuelan crisis has eroded its regional image and credibility.

All these events seem to indicate that policies following neo-liberal dictates in the economic sphere and policies fostering closer relations with the US and other global centres of power (like the EU) in the political sphere are waxing. This could result in the region once again adopting a simple economic model based on the idea that regional integration is an instrument for improving its insertion into global markets without worrying too much about the quality of that insertion. Similarly, the idea that globalisation works against the promotion of autonomous policies is also likely to re-return. If this happens, it would lend further impetus to the reassertion of hegemony.

This picture is not yet entirely clear, and one may well ask whether a new cycle is emerging, or whether we are simply entering a period of flux and uncertainty. Has the dust really settled to the extent that we can be sure a new cycle is emerging? ${ }^{2}$ Perhaps not, but recent events do point to the former rather than the latter. It is clear that Mercosur has moved away from elements of the economic and political models that existed in the post-hegemonic era, and that the lowest common denominators in CELAC and UNASUR are no longer working. These are signals that Latin American regionalism is experiencing something more than a period of flux and uncertainty.

\section{Notes}

1. Spanish and Portuguese acronyms of the regional schemes will be used in this article.

2. This question was raised by an anonymous reviewer, and I am indebted to him or her for the suggestion 


\section{References}

Agreement between the President of the Bolivarian Republic of Venezuela and the President of the Council of State of the Republic of Cuba for the implementation of the Bolivarian Alternative for the Americas. 2004. Havana, 14 December. At http://www.cuba.cu/gobierno/discursos/2004/ing/ a141204i.html [Accessed on 10 September 2017].

Ambito.com [online]. 2017. 'Afirman que Macri y Temer trabajarán para eliminar barreras y liberar el comercio en el Mercosur.' 3 February.

Arrosa Soares, M S. 2005. 'Autonomia e Interdependência nas Relações Internacionais na América Latina.' At http://www.cedep.ifch.ufrgs.br/Textos_Elet/Alas/Maria\%20Susana\%20A.pdf [Accessed on 12 September 2017].

Brander, J A. 2005. Strategic Trade Policy. NBER Working Paper Series No. W5020. Cambridge: National Bureau of Economic Research.

Briceño Ruiz, J. 2010. 'From the South America Free Trade Area to the Union of South American Nations.' Latin America Policy 1 (2): 208-229.

2013. 'Ejes y modelos en la etapa actual de la integración económica regional en América

Latina.' Estudios Internacionales 45 (175): 9-39.

2017. 'Latin America beyond the Continental Divide: Open Regionalism and Post-Hegemonic Regionalism Co-existence in a Changing Region.' In J Briceño-Ruiz and I Morales (eds), Post-Hegemonic Regionalism in the Americas. Toward a Pacific-Atlantic Divide? Abingdon: Routledge, pp. 73-98

Briceño Ruiz, J and A Ribeiro Hoffmann. 2015. 'Post-hegemonic regionalism, UNASUR, and the reconfiguration of regional cooperation in South America.' Canadian Journal of Latin American and Caribbean Studies/Revue canadienne des études latino-américaines et caraïbes 40 (1): 48-62.

Buck, K. 2010. 'The European and Latin American Integration Projects.' In R Stemplowski (ed), Europe and Latin America: Looking At Each Other. Warsaw: Polish Institute of International Affairs, pp. 383-413.

Consejo Argentina de Relaciones Internacionales (CARI). 2015. 'Reflexiones sobre los desafíos externos de la Argentina: Seremos afuera lo que seamos adentro. Primer Documento'. At http://www. cari.org.ar/pdf/documento_grupoconsenso.pdf [Accessed on 22 June 2016].

Costa Vaz, A. 2010. 'La Comunidad de Estados Latinoamericanos y Caribeños. La factibilidad y necesidad de un nuevo organismo regional.' Nueva Sociedad 27: 4-8.

Dabène, O and K Parthenay. 2017. 'Regionalism in Central America: an "all-in” strategy' In J Briceño-Ruiz and I Morales (eds.), Post-Hegemonic Regionalism in the Americas: Toward a Pacific-Atlantic Divide? Abingdon: Routledge, pp. 159-173.

Deacon, B, I Ortiz and S Zelenev. 2007. 'Regional Social Policy.' DESA Working Paper No. 37 ST/ ESA/2007/DWP/37. New York: United Nations Department of Economic and Social Affairs.

Di Filippo, A. 1995. 'Transnationalization and integration of production in Latin America.' CEPAL Review 57: 133-149.

Economic Commission for Latin America (ECLA). 1959. The Latin America Common Market. Santiago: ECLA. 
Economic Commission for Latin America and the Caribbean (ECLAC). 2004a. Changing Production Patterns with Social Equity. The Prime Task of Latin American and Caribbean Development in the 1990s. Santiago: United Nations-ECLAC.

2004b. Open regionalism in Latin America and the Caribbean: Economic Integration as a Contribution to Changing Production Patterns with Social Equity. Santiago: ECLAC.

2014. Regional Integration: Towards an Inclusive Value Chain Strategy, Santiago: ECLAC.

Egler, I, W Peres and S Rovira (eds). 2014. La integración productiva latinoamericana mediante proyectos regionales en ciencia, tecnología e innovación. Santiago: Naciones Unidas.

Escudé, C. 1992. El realismo periférico. Fundamentos para la nueva política exterior argentina. Buenos Aires: Planeta.

Fajnzylber, F. 1990. 'Industrialization in Latin America: From the "Black Box" to the "Empty Box."' Cuadernos de la CEPAL 60 LC/G.1534-P. Santiago: ECLAC.

Gómez Mera, L. 2015. 'International Regime Complexity and Regional Governance: Evidence from the Americas.' Global Governance 21: 19-42

Halliday, F. 1994. Rethinking International Relations. Basingstoke: Palgrave Macmillan.

Hettne, B and F Söderbaum. 2000. 'Theorising the Rise of Regionness.' New Political Economy 5 (3): 457-472.

Jaguaribe, H. 1968. Desarrollo económico y desarrollo político. Buenos Aires: Eudeba. 1979. 'Autonomía periférica y hegemonía céntrica. Estudios Internacionales 46: 91-130.

1985. El nuevo escenario internacional, Autonomía periférica y hegemonía del centro. México:

Fondo de Cultura Económica

Joint Declaration Venezuela-Cuba, I Summit, Havana, Cuba, 14 December 2004. At http://alba-tcp. org/en/contenido/joint-declaration-venezuela-cuba [Accessed on 22 June 2017].

Lawrence, R Z. 1996. Regionalism, Multilateralism and Deeper Integration. New York: The Brookings Institution.

Lima Presidential Declaration. 2011. At http://www.sice.oas.org/TPD/Pacific_Alliance/Presidential_ Declarations/I_Summit_Lima_Declaration_s.pdf [Accessed on 22 June 2017].

Nolte, D. 2014. Latin America's New Regional Architecture: A Cooperative or Segmented Regional Governance Complex? RSCAS 2014/89. Florence: Robert Schuman Centre for Advanced Studies Global Governance Programme.

Palabras de Cristina de Kirchner en Acto de Asunción como Presidenta del Mercosur, Palabras de la Presidenta Cristina Fernández De Kirchner, en el Acto de Asunción como Presidenta Pro Tempore del Mercosur. At http://www.casarosada.gob.ar/informacion/archivo/16494-blank-6432444 [Accessed on 15 June 2017].

Perfil [online]. 2017. 'Macri y Temer pidieron darle un impulso "histórico" al Mercosur.' 7 February. At www.perfil.com [Accessed on 15 June 2017].

Perroux, F. 1966. 'Intégration économique. Qui intègre? Au bénéfice de qui s'opère l'intégration?' Économie appliquée XIX (3-4): 389-414.

Pinheiro, G S. 2008. 'O Mundo Multipolar e a Integração Sul-Americana.' Temas \& Matizes 14: 5872.

Prebisch, R. 1959. 'El Mercado Común Latinoamericano.' Comercio Exterior IX (9): 509-513. 
Puig, J C. 1980. Doctrinas internacionales y autonomía latinoamericana. Caracas: Instituto de Altos Estudios de América Latina de la Universidad Simón Bolívar.

1986. 'Integración y autonomía de América Latina en las postrimerías del siglo XX.' Integración Latinoamericana 11 (109): 40-62.

Renard, M. 2001. 'Intégration internationale des pays en développement et en transitions et spécialisations regionals.' Revue Région et Développment 13: 5-9.

Richardson, J D. 1990. 'The political economy of strategic trade policy'. International Organization XLIV (1): 107-135.

Riggirozzi, P. 2010. Region, Regioness and Regionalism in Latin America. Towards a new Synthesis. LATN Working Paper no. 130. Buenos Aires: Latin America Trade Network.

2012. 'Reconstructing Regionalism: What does development have to do with it?' In D Tussie and P Riggirozzi (eds), The Rise of Post-Hegemonic Regionalism. The Case of Latin America. Dordrecht: Springer, pp. 17-39.

2014. 'Regionalism through social policy: collective action and health diplomacy in South America.' Economy and Society 43 (3): 432-454

2017. 'Regional integration and welfare: Framing and advocating pro-poor norms through Southern regionalisms.' New Political Economy 22 (6): 661-675.

Rojas Aravena, F. 2012. 'La CELAC y la integración latinoamericana y caribeña. Principales claves y desafíos.' Nueva Sociedad 240: 16-27.

Rucker, L. 2004. 'La contestation de l'ordre international: les États révolutionnaires.' Revue internationale et stratégique 54: 109-118.

Saltalamacchia Z N. 2014. 'The Mexican Agenda in Latin America: The Pacific Alliance.' Anuario de la Integración Regional de América Latina y el Caribe 10: 421-438.

Sanahuja, J A. 2010. 'La construcción de una región: Suramérica y el regionalismo postliberal'. In M Cienfuegos and J A Sanahuja (eds), Una región en construcción. UNASUR y la integración en América del Sur. Madrid: Fundación CIDOB, pp. 87-136.

Serbin, A. 2010. 'Despertares y anarquías: avatares de la cooperación regional.' Foreign Affairs Latinoamérica 10 (3): 6-11.

Sunkel, O. 1991. El desarrollo desde dentro. Un enfoque neo-estructuralista para América Latina. México: Fondo de Cultura Económica.

Tussie, D and P Riggirozzi. 2012. 'The rise of post-hegemonic regionalism in Latin America.' In D Tussie and P Rigirozzi (eds), The Rise of Post-Hegemonic Regionalism: The Case of Latin America. Dordrecht: Springer, pp. 1-16.

United Nations Conference on Trade and Development (UNCTAD). 2007. Regional Cooperation for Development. Trade and Development Report 2007. New York: United Nations.

Veiga, P M and S Rios. 2006. 'América do Sul: A integração pode sobreviver ao nacionalismo econômico?' FLACSO Series Brief 32. Buenos Aires: Latin America Trade Network.

www.ambito.com [online]. 2017. 'Afirman que Macri y Temer trabajarán para eliminar barreras y liberar el comercio en el Mercosur.' 3 February. At http://www.ambito.com/871689-afirman-quemacri-y-temer-trabajaran-para-eliminar-barreras-y-liberar-el-comercio-en-el-mercosur [Accessed on 22 June 2017]. 
www.perfil.com [online]. 2017. 'Macri y Temer pidieron darle un impulso “histórico" al Mercosur.' 7 February. At http://www.perfil.com/politica/macri-con-temer-pidieron-darle-un-impulso-historico-al-mercosur.phtml [Accessed on 22 June 2017].

Yeates, N. 2005. Globalization' and Social Policy in a Development Context Regional Responses. Social Policy and Development Programme Paper No. 18. Geneva: United Nations Research Institute for Social Development.

\section{Acknowledgments}

This paper was written during my sojourn as a Visiting Scholar at the Centre of Latin American and Caribbean Studies (CIALC) of the Autonomous National University of Mexico (UNAM) in the semester January-June 2017. I am indebted to the Dirección General de Asuntos del Personal Académico of UNAM (DGAPA) for funding my stay at the CIALC-UNAM. It would also like to thank Professors Ruben Ruiz, Mario Vázquez and Rodrigo Páez Montalban for their assistance and generosity during my semester at the CIALC.

\section{About the author}

José Briceño Ruiz holds a $\mathrm{PhD}$ in Political Science from the Institut d'Etudes Politiques d'Aix-en-Provence, France. He is a professor and researcher at the Faculty of Economics and Administration and Centro de Pensamiento Global (CEPEG) at the Universidad Cooperativa de Colombia. He was professor at the Faculty of Social and Economic of the University of the Andes, Venezuela, between 2003-2017. He is a specialist on Regional Integration and International Political Economy. He has written and edited numerous books about regional integration, the most recent being Brazil and Latin America: Between the Separation and Integration Paths (Lanham, Maryland: Lexington Books, 2017) in collaboration with Andrés Rivarola Puntigliano; and Post-Hegemonic Regionalism in the Americas: Towards a Pacific vs. Atlantic Divide? (London: Routledge, 2017), in collaboration with Isidro Morales (Tec de Monterrey). 


\section{Tempos de Mudança no Regionalismo Latino-Americano}

Resumo: Depois de uma década dominada por iniciativas pós-liberais ou póshegemônicas, o advento de governos conservadores na Argentina e no Brasil e a crise na Venezuela levaram a um ressurgimento do regionalismo aberto. Isso poderia ter consequências importantes em uma região dividida por diferentes modelos de integração econômica e cooperação política. O estudo avalia o complexo e cambiante cenário do regionalismo latino-americano. Em primeiro lugar, traça a trajetória do regionalismo na América Latina nos últimos anos. Em segundo lugar, examina modelos de integração econômica e cooperação política. Em terceiro lugar, analisa o funcionamento desses modelos na era pós-hegemônica. Por último, analisa o surgimento de um novo ciclo regional e suas implicações para a integração e cooperação regional.

Palavras-chave: Regionalismo; Integração Regional; Cooperação; América Latina; Pós-hegemônico.

Received on 4 October 2017, and approved for publication on 23 July 2018. 